\title{
The influence of organization atmosphere and school leadership on teacher performance in senior high school
}

\author{
Tri Handayani ${ }^{1}$, Happy Fitria ${ }^{2}$, Yenny Puspita ${ }^{2}$ \\ ${ }^{1}$ Sekolah Menengah Atas PGRI 2 Palembang, Indonesia \\ ${ }^{2}$ Universitas PGRI Palembang, Indonesia
}

\begin{tabular}{l} 
Article Info \\
\hline Article history: \\
Received Jul $19^{\text {th }}, 2021$ \\
Revised Aug $13^{\text {th }}, 2021$ \\
Accepted Aug $30^{\text {th }}, 2021$ \\
\hline Keyword: \\
Organization atmosphere \\
School leadership \\
Teacher performance
\end{tabular}

Teacher performance

\begin{abstract}
This objective of the study was to know 1) the influence of organization atmosphere on the teacher performance, 2) the influence of school leadership on the teacher performance and 3) the influence of organization atmosphere and school leadership on the teacher performance. This research uses quantitative methods. The population was the all teachers at Senior High School with the total 69 teachers and 1 headmaster. The Sampling was use random sampling technique at 25 respondents and multiple linear regression formula. Data collection is done by questionaire and documentations. Data were analyzed descriptively using SPPS Version 20 for windows. From the results of the study it can be concluded that 1) there was an influence of organization atmosphere on the teacher performance, 2) there was an influence of school leadership on the teacher performance and 3) there was an influence of organization atmosphere and school leadership on the teacher performance.
\end{abstract}

(C) 2021 The Authors. Published by IICET.

This is an open access article under the CC BY-NC-SA license

(https://creativecommons.org/licenses/by-nc-sa/4.0

\section{Corresponding Author:}

Handayani, T.,

Sekolah Menengah Atas PGRI 2 Palembang, Indonesia

Email: trihandayani0205@gmail.com

\section{Introduction}

The teacher is one of the most important resources for the progress of a school. Teachers have a duty to educate, teach and train. Educating means to continue and develop the values of life, teaching means to continue and develop the science pengetah agi uan, training means developing skills in students. In carrying out these duties and responsibilities, a teacher is required to have certain abilities and skills.

Teacher performance is influenced by various factors that are interrelated with each other to form the quality of the work of the teacher itself. Gibson in (Suharsaputra, 2010: 147) states that "The factors that influence performance are individual variables, organizational variables and psychological variables." Based on this opinion, the factors that influence teacher performance include teacher competence, principal leadership, and organizational environment. Principal leadership is related to the performance of teachers. The quality of the principal's leadership affects the teacher's response to his work.

According to Robbin (2003: 432) leadership is the ability to influence a group towards achieving goals. Good leadership can be seen from the performance of the principal which appears in the managerial aspects that are owned. This is in line with the opinion of Hersey and Blanchard (1982: 5) which states, " It is generally a great that there are at least three areas of skill necessary for carrying out the process of management: technical, human, conceptual ." The three managerial skills relate to teacher performance, namely in the implementation of tasks which in turn will also relate to the achievement of educational goals. 
In such conditions, the leadership of the principal plays an important role, because it can provide an organizational athmosphere that allows teachers to work with passion. Another factor that also affects teacher performance is the school organizational athmosphere.

From the results of preliminary observations made by researchers, carried in a Gustus to the school in 2020, researchers discovered a few things related to organizational athmosphere and leadership to the school on teacher performance. In general, the implementation of leadership activities carried out by school principals has been carried out well, but in fact there are still some teachers who think that kindness (the principal's discretion) makes them careless so that they consider all their obligations to be taken lightly. This can be seen from the teaching and learning process, some are caught arriving late and going home early, not making learning tools, some teachers are less mingled with the whole group only and lack of communication and leaving the classroom during teaching hours, but teachers should be role models. for students at school. This shows that the performance of teachers in these schools is still low.

Based on these preliminary observations, the researcher believes that SMA PGRI 2 Palembang is worthy of being used as a place for this research.

\section{Developing Theoretical Framework, Thinking Framework and Testing Hypothesis}

\section{Theoretical Descriptions}

1. Teacher Performance

a. Definition of Teacher Performance

Performance adal a $\mathrm{h}$ willingness of a person or group of people to do activities and refine them in accordance with his responsibilities with the expected results (Veithzal, 2008: 15), performance in general is the face and image of the employee that is reflected from an organization, but in the application Correctly it is not easy, because human nature consists of various characteristics and has different feelings, dispositions and abilities (Ruky, 2006: 213).

Performance as the results of the work function / activity of a person or group in an organizational activity that is influenced by various factors to achieve organizational goals within a certain period. The function of the activity or work referred to here is the implementation of the results of the work or activities of a person or group which is the authority and responsibility of an organization. The implementation of the work results / work performance is directed to achieve organizational goals within a certain period of time. (Pabundu Tika. 2006: 121-122) Yuwalliatin (in Mangkuenegara. 2006: 67) says that performance is measured by instruments developed in studies that are incorporated into measures performance in general is then translated into basic behavioral assessments, including: 1) Work quantity, 2) Quality of work, 3)Knowledge of work.

Pedagogic competence is the ability to manage student learning. Yamin , (2010: 9) calls this competency the learning management competence. This competence can be seen from the ability to plan learning programs, implement or manage the interaction of the learning process, and conducting the assessment process and hasi 1 learning.

Professional competence is the ability that teachers must have in planning and implementing the learning process. Teachers have a duty to direct student learning activities to achieve learning objectives, for that teachers are required to be able to deliver learning materials. Teachers must always update, and master the subject matter presented. Self-preparation of the material is attempted by searching for information through various sources such as reading the latest books, accessing the internet, always following the latest developments and progress on the material presented.

Teacher personality competence includes all elements, both physical and psychological. So that it can be seen that every action and behavior of the teacher is a reflection of the teacher's personality, as long as it is done with full awareness. Every word, action, and positive behavior will improve selfimage and personality which ultimately affects the teacher's authority.

Social competence according to Arikunto (2002: 239) is the teacher's ability to communicate social with students, fellow teachers, school principals, and the community. From this statement, it appears that social competence must indeed be possessed by a teacher as part of the community to communicate and interact effectively with students, educational staff, parents / guardians of students, and the surrounding community. 
b. Performance assessment.

In the employee performance appraisal, it does not only assess physical results, but the overall implementation of work involving various fields such as work ability, craft, discipline, work relations or special matters in accordance with the field and level of work they hold. According to Dessler (2000) there are five factors in popular performance appraisals, namely:

1) Job performance, including: accuracy, thoroughness, skills, and acceptance of output .

2) The quantity of work, including: volume of output and contribution .

3) Leadership needed, including: needing advice, direction or improvement .

4) Discipline, including: attendance, sanctions, documents, regulations, dependability and timeliness .

5) Cooperative The respondent's assessment of the willingness to cooperate with other people (fellow members of the organization).

6) Initiative Respondents' assessment of the enthusiasm for carrying out new tasks and in enlarging their responsibilities.

7) Personal quality. Respondent's assessment of personality, friendliness and personal integrity. (Dessler. 1997: 152)

2. Organizational Athmosphere

a. Understanding Organizational Athmosphere

Organizational athmosphere is determined by the social relationships of the people in the organization, and the reward system used to motivate workers. Organizational athmosphere is basically the result of perceptions according to Gibson, Ivancevic , and Donelly (2009: 5) that " Organizations, large and small, domestic and global, successful and unsuccessful" . Davis in Sutisna (2009: 2) states that organizational athmosphere can be in one place on a continuum that moves from pleasant to neutral to unpleasant. Organizational athmosphere is very important for the success of an organization and different organizational athmospheres.

Thus, the dynamics of the leadership of the principal and the group (teachers and staff) are seen as the key to understanding variations in the school athmosphere, and each of these verifications will contribute to the variation in performance undertaken by all members of the school organization. Based on several definitions of school organizational athmosphere as described above, it can be interpreted that the school organizational athmosphere is a condition, in which the school and its environment are in a very safe, comfortable, peaceful and pleasant state for teaching and learning activities. A good organizational athmosphere has a significant role in the ongoing process of education.

Organizational athmosphere is defined as a broad measure of people's expectations about the likes of the organization they are meeting with Organizational athmosphere can serve as an indicator of whether or not the employees' expectations are met in the organization.

Nitisemito (1977: 97) states that organizational athmosphere is everything that is around the workers that can influence them in carrying out their assigned tasks. According to Nitisemino, organizational athmosphere is largely determined by management attitudes towards the organization and how the relationship between employees and between groups within an organization. Every organization has different cultures, traditions and methods, which as a whole will shape the athmosphere in human relations within the organization. Athmosphere in an organization as well as personality in humans. In building a athmosphere that can motivate employees to produce and get satisfaction, management needs to be aware

b. The Organizational Athmosphere Dimension

The dimensions of organizational athmosphere are elements, factors, traits, or characteristics of organizational athmosphere variables. Litwin and Stringer (1986) describe organizational athmosphere into nine (9) dimensions, namely:

1) Structure. Employees perceive themselves to know the rules, regulations, existing procedures and certain bureaucracies in the organization.

2) Responsible. Employees perceive themselves to be leaders in doing their own work, without the need to review the decisions they make. 
3) Appreciation. Employees perceive an award received is the result of a job well done.

4) Warmth. Employees see the overall friendship formed from informal social group interactions within the organization .

5) Endorsement. Employees see that the provision of assistance is based on the reciprocal relationship between superiors and subordinates.

6) Standard. Employees see performance standards that are stated implicitly and explicitly in the organization.

7) Conflict. Employees see a conflict occurs because of differences in opinion of each member in the organization.

From the various descriptions above, it can be emphasized that organizational athmosphere is a trait that describes the atmosphere of an organizational psychological environment that shows the content and strength of the influence, including the values, norms, attitudes and feelings of the members of the organization.

c. Organizational Athmosphere Factors

Kolb and Rubin (1984: 343) There are 7 (seven) aspects that can identify organizational athmosphere in an organization, namely:

1) Conformity. Conformity is formed because of the same feelings between employees about the many rules, procedures and laws in carrying out work.

2) Responsibilities: member in the organization has the responsibility of msing to realize the objectives of the company

3) Standard: The organization's emphasis on display quality also makes its products well known. Employees are challenged to run kom i tmen .

4) Rewards per a saan of the employee, the employee bhwa hard work will surely be known and assigned the appropriate reward for his efforts.

5) Organizational clarity. The feeling of employees that the company is well organized and has clear goals .

6) Support and warmth

7) friendship among all members of the organization is the most important value for forming good relationships in the work environment.

8) Leadership. Employees accept the existing leadership in the company and all its decisions. (Kolb \& Rubin. 1984: 343 )

Likert (in Gibson and Donnely), Organizational athmosphere is able to manage organizational needs optimally so that it can create an internal environment (psychological environment) that supports the achievement of organizational or company goals. Organizational athmosphere consists of several factors, including:

1) Structur namely the degree of the rules imposed on organizations, their suppression or restriction by the employer or the organization of the members of the organization.

2) Standard, namely the result of work requested and clarity of expectations related to work performance.

3) Responsibility, namely the responsibility to measure members' perceptions of the amount of responsibility entrusted to them. d.Reward. Namely expectations and rewards in work situations, gifts indicate acceptance of behavior and deeds, while punishment shows rejection of behavior and deeds.

4) Organizational identity, namely group loyalty within employees to the company.

5) Organization $C$ larity . Namely the clarity of objectives and policies implemented by the organization. Everything is clearly organized and not confusing, obscene or chaotic.

These six factors can assess how organizational members perceive their organizational environment. ( LN Jewe 11 \& M. Siegall. 1998: 374-379 ) 
3. Principal Leadership

a. Definition of Principal Leadership

Behaviors leadership is often the focus of attention in the research. Research activities that use learning organizations as a population or sample of institutions focus mostly on behavior, work ethic, work styles, motivation, managerial abilities and other aspects related to principal leadership. The principal is a functional teacher who is given the task to lead a group where there is an interaction between the teacher who gives lessons and students who accept the lesson.

Principal leadership is related to the performance of teachers. The quality of the principal's leadership affects the teacher's response to his work. According to Robbin (2003: 432) leadership is the ability to influence a group towards achieving goals. Good leadership can be seen from the performance of the principal which appears in the managerial aspects that are owned. This is in line with the opinion of Hersey and Blanchard (1982: 5) which states, " It is generally a great that there are at least three areas of skill necessary for carrying out the process of management: technical, human, conceptual ". The three managerial skills relate to teacher performance, namely in the implementation of tasks which in turn will also relate to the achievement of educational goals. In such conditions, the leadership of the principal plays an important role, because it can provide an organizational athmosphere that allows teachers to work with passion.

b. Types of Leadership, There are various types of leadership mentioned by Soewadji Lazaruth (1992: 62), including:

1) Viewed from the emergence of a leadership

2) Official Leadership, also known as official leadership. This leadership arises because it is appointed or appointed by a power outside the group. Example: principal, head of office, etc.

3) Emerging Leadership, namely leaders who are appointed or selected by the group because they have outstanding abilities when compared to other group members.

4. Judging from the way of approach

Authoritarian Leadership. Authoritarian leadership arises from the leader's belief that his function and role are to rule, regulate and supervise group members. The advantage of an authoritarian leader is that discipline can be well controlled, and all work can take place in an orderly and orderly manner. While the weaknesses include:

a. The leader places himself outside the group, so that there is a gap between the leader and the leader.

b. Staff or groups cannot develop properly, because they do not have the opportunity to participate in decision making.

c. If the group consists of weak people, they will become robots. Conversely, if they are able, tensions will arise. Even if there are strong people, opposition groups will emerge.

d. The relationship between group members is not harmonious.

e. The group works in a stressful atmosphere.

f. When a problem arises, it is not resolved openly and objectively, but the scapegoat is sought.

g. When the leader is not there, the situation will be chaotic.

h. Most communication occurs only between superiors and subordinates, while communication between group members is lacking.

\section{Laissez-Faire Leadership}

Leadership laissez-faire is a leader who believes that his role is simply to accompany and serve when needed. Laissez-faire leadership assumes that teachers or group members are adults and mature people. So that they can organize and direct themselves. For truly mature groups, this leadership weakness is not so visible, but it still has weaknesses, including:

1. Group members do not develop because they do not receive sufficient guidance and direction .

2. Group members do not feel any leadership in the group.

3. The atmosphere is disorderly and orderly.

4. When the group consists of weak people, the atmosphere gets worse.

5. When a problem arises, it is never completely resolved and satisfactorily.

\section{Democratic Leadership}


Democratic, leader believes that its role is to encourage, guide, bringing together the power of the group to the maximum and to cooperate with the group in order to achieve a common goal. The main principle of democratic leadership is to involve all people in the process of determining and determining strategies in an effort to achieve common goals. Every decision making is always based on deliberation and consensus. In addition, it is the principle of continuous development of group members so that their quality is increased.

The duties of a democratic leader in the coaching process include:

1. Developing unity and group unity .

2. Encourage the courage to experiment.

3. Develops the reasoning power of group members.

4. Builds a sense of security and self-confidence in the group.

5. Helps the group to see clearly the limits of its authority.

6. Develop interaction and exchange experiences between group members.

7. Develop group member leadership .

\section{Leadership Function}

According to Wahjosumidjo (2011: 41-48) the function of leaders is differentiated according to the opinion of two experts, namely:

1. James AF Stoner

In order for a group to operate effectively, a leader has two main functions, including: Task related or problem solving function, where the leader provides advice in solving problems and contributes information and opinions. Group maintenance function or social function, namely the leader helps the group operate more smoothly and the leader gives approval or completes other group members.

2. Selznick

According to Selznick, there are four kinds of tasks pe $\mathrm{n}$ ting a leader among others:

a. Defining the mission and role of the organization

b. The mission and role of an organization can only be properly formulated or defined, if a leader first understands the structural assumptions of an organization.

c. Embodiment of organizational goals

d. The leader must create wisdom into the order or decision on the means to achieve the planned goals

e. Maintaining organizational integrity

f. The leader represents the organization to the public and to its staff, just as a leader tries to get his subordinates to follow his decisions so that this function can be carried out. Therefore, the role of a leader is very important to maintain organizational integrity.

g. Controlling internal conflicts that occur within the organization

A leader must try to understand and study aspects related to conflict, such as the process of conflict, the characteristics of conflict, sources of conflict, levels of conflict, conflict management styles, and the role of leadership in conflict resolution.

So, it can be concluded that the principal's leadership is the ability or readiness of a school principal to influence and direct teachers to achieve organizational goals. The principal leadership indicators are: Influence. Directing, Guide, Set, Encourage teacher performance and Have a sense of friendly and close to the teachers

\section{Full of Consideration}

Relevant research studies

1. In the journal of management, leadership and education supervision Volume 6, No. 1, January-June 2021 with the title " The Effect of Principal Management and Teacher Professionalism on Teacher Performance " (Puspitasari , Y., Tobari \& Kesumawati , N. 2021) that: (1) principal management has an effect on teacher performance in SD Negeri Tanjung Raja District; (2) teacher professionalism has no effect on teacher performance in SD Negeri Tanjung Raja District; (3) school management and teacher professionalism together do not affect teacher performance at SD Negeri Tanjung Raja. The similarities in this study are both examining teacher performance as the dependent variable (Y), while the difference in previous research which is the variable $(\mathrm{X})$ is principal management and teacher professionalism, while this research variable $(\mathrm{X})$ is organizational athmosphere and principal leadership. . 
2. In the Journal of Intellectuals: Islam, Social, and Science Vol. 9, No. 1, June 2020 with the title the influence of work environment and work motivation on the performance of high school teachers in Muara Padang District ( Marphudok, Lian , B. \& Fitria , H. 2020), the results obtained from his research There is a positive and significant influence of the work environment on performance high school teacher in Muara Padang district, which means the alternative hypothesis (Ha) in testing hypothesis 1 is accepted; There is a positive and significant effect of work motivation on the performance of high school teachers in Muara Padang district, which means that the alternative hypothesis $(\mathrm{Ha})$ in testing hypothesis 2 is accepted; There is an influence of work environment and work motivation on the performance of high school teachers in Muara Padang district, which means that the alternative hypothesis $(\mathrm{Ha})$ in testing hypothesis 3 is accepted. The equation of this research is that both of them examine teacher performance as the dependent variable (Y), while the difference in previous research which is the variable $(\mathrm{X})$ is the work environment and work motivation, while in this study the variable $(\mathrm{X})$ is organizational athmosphere and school principal leadership.

3. In the Journal of Intellectuals: Islam, Social, and Science Vol. 9, No. 1, June 2020 with the title The Influence of Organizational Culture and Principal Leadership on Teacher Performance in Tanjung Raja District Public High School (Yulizar, A rafat, Y. \& Rohana 2020) Research results show that:

a. There is a significant influence between organizational culture on teacher performance in SMA Negeri Tanjung Raja District;

b. There is a significant influence between principal leadership on teacher performance in SMA Negeri Tanjung Raja District; (3) there is a significant influence between organizational culture and principal leadership together on teacher performance at SMA Negeri Tanjung Raja District.

\section{Method}

In accordance with the problems raised in this study, the research location used as a data source is at SMA PGRI 2 Palembang. The research time starts from the initial observation in writing the background of the problem on August 2020 to completion. The problem that will be discussed in this research is whether there is an influence of organizational athmosphere and principal leadership on teacher performance at SMA PGRI 2 Palembang. For this reason, researchers try to use a method that is appropriate to the problem under study. As it should be, a study will not achieve the actual research criteria if it does not use an appropriate research method. With the right method, it is hoped that a study will become scientific, logical, systematic and legally accountable research. Berlkut is a method used by researchers in

A quantitative approach me rupakan efforts to measure vari- existing variables in the study (X1, X2 and $\mathrm{Y}$ ) and then look for relationships between these van'abel. This study uses quantitative methods to the type of correlational research for this study aims to meIi $h$ at the relationship between variables. Pearson Product Moment Conelation is sala $\mathrm{h}$ a technique to look for a correlation between two variables that often digun ak 's. This correlation technique was developed by Karl Pearson, who is often known as the Pearson Correlation Technique (Sugiyono 2013). In this study, to calculate the correlation using the SPSS 20.0 application. 0.

Population is a generalization area consisting of objects that have certain qualities and characteristics that are determined by researchers to study and then draw conclusions (Sugiyono 2011: 119). In this study, the research subjects were teachers at SMA PGRI 2 Palembang. The population in this study were principals and teachers in SMA PGRI 2 Palembang.

The size of the research sample size, Arikunto (2002: 107) suggests that if the subject is less than 100, it is better to take all of them so that the research is a population study. The sample in this study was the principal and teachers of SMA PGRI 2 Palembang City. In this study, the total sample of teachers was 69 people plus 1 school principal. So that the total sample is 70 people. To find out the number of samples that will be used by researchers using a formula with an error rate of $5 \%$. Based on the calculation using the formula that the researchers did, it is known that the number of teachers to be sampled is 59 teachers using an instrument in the form of a questionnaire to measure organizational athmosphere, principal leadership and teacher performance.

1. Conceptual definition: organizational athmosphere, principal leadership, and teacher performance

2. Variable operational definitioN: principal supervision, organizational athmosphere, and teacher performance.

Teacher performance can be seen after evaluating teacher performance. To measure teacher performance variables, namely personality aspects, methodological aspects, technical aspects, and development aspects. 
Data collection technique: questionnaire, observation and documentation. In this study, the data analysis technique used inferential statistics, namely simple linear correlation test, multiple linear correlation test, $\mathrm{T}$ test, and $\mathrm{F}$ test. To find out whether data analysis for hypothesis testing could be continued or not, a prerequisite analysis was carried out.

The hypothesis tested in this study is the influence of the independent variable Organizational Athmosphere (X 1 ) and Principal Leadership (X 2 ) on Teacher Performance (Y) either individually or collectively. After obtaining the $t$ value using the SPSS version 20 application, to display the results, the following conditions apply 1 ) if $t$ count $\geq t$ table then $\mathrm{H} 0$ is rejected (significant relationship), 2) if $t$ count $\leq t$ table $\mathrm{H} 0$ is accepted (insignificant relationship). To find out the t table, the provisions of $n-2$ are used at the level of significance of $5 \%$ (error rate of $5 \%$ ) or the level of confidence of $95 \%$ or 0.95 . So if the error rate of a variable is more than $5 \%$, it means that the variable is not significant.

\section{Results and Discussions}

\section{Organizational athmosphere}

Based on the items of the organizational athmosphere instrument questioning instrument, which amounted to 25 items, the lowest score was 69 and the highest score was 125, with 25 respondents.Based on the calculation results, the results of the organizational athmosphere at SMA PGRI 2 Palembang include conformity. which is formed by the same feeling among the employees about the many regulations, pros e dur and the law in carrying out the work, responsibility responsibility: where $\mathrm{s}$ ach member in the organization has the responsibility of msing to achieve company goals, standards : the pressure from the organization on quality of appearance and make the product famous. Employees are challenged to uphold the commitment, rewards the feelings of employees, $b$ a hwa hard work of employees would have known and obtain a modest honorarium for his efforts, the clarity of the organization feeling the employees that the company is well organized and has a clear purpose, the support and warmth of friendship among All members of the organization are the most important values for forming good relationships in the work environment, leadership where employees accept leadership in the company and all its decisions .

\section{Leadership}

Based on the items of the organizational athmosphere instrument questions, which amounted to 25 items, the lowest score was 72 and the highest score was 125 with 25 respondents. Principal leadership is the ability or readiness of a school principal to influence and direct teachers to achieve organizational goals. The principal leadership indicators are: influencing, directing, guiding, regulating, encouraging the performance of teachers, having a sense of friendship and being close to the teachers, full of consideration .

\section{Teacher Performance}

Based on the items of the organizational athmosphere instrument questions, which amounted to 25 items, the lowest score was 75 and the highest score was 125 with 25 respondents. The results of the calculation show the performance of SMA 2 PGRI Palembang teachers for the level of discipline, creativity, cooperation, responsibility for the work done.

\section{Testing Data Analysis Requirements}

1. Data Normality Test

2. Homogeneity Test

\section{Hypothesis Test}

1. First Hypothesis (Effect of organizational athmosphere on teacher performance)

2. Second Hypothesis (Effect of principal leadership on teacher performance)

3. The influence of organizational athmosphere (X1) and principal leadership (X2) on teacher performance

\section{Discussion}

Based on the research results described above, it is found that the variable (X1) Organizational Athmosphere has an influence on each other. Based on the $t$ test, the coefficient value obtained is 0.012 . While the table that has been set is 0.05 . This means that $t$ count $<t$ table of coefficient numbers obtained is 0.002 . While the $t$ table is 0.05 . This means that $t$ count $<\mathrm{t}$ table. Furthermore, organizational athmosphere (X1) and leadership 
have an influence on teacher performance $(\mathrm{Y})$. This is also indicated by the coefficient figure obtained, which is 0.011 . While the $t$ table is 0.05 . This means that $t$ count $<t$ table. Then the organizational athmosphere (X1) and leadership have an influence on teacher performance (Y). This is indicated by the coefficient figure obtained, which is 0.011 . While the significant level is $5 \%$. This means that $t$ count $<\mathrm{t}$ table. . Thus, there is a significant influence between organizational athmosphere (X1) on teacher performance $(\mathrm{Y})$, there is a significant influence between Principal Leadership (X2) on teacher performance $(\mathrm{Y})$ and there is a significant influence between organizational athmosphere (X1), leadership. principal h (X2) on teacher performance (Y) .

Many factors influence teachers who are active at work and it is often found that teachers who are active in work suddenly are not at all excited to do something because of home (personal) problems that are brought to the workplace. Teachers will prefer to work in a comfortable and pleasant atmosphere. Teachers who feel liked, accepted by their peers or admired will be more interested in working than those who are ignored or ostracized by their peers. The teacher's desire to know and understand something is not always the same.

The results of this study prove that the work ability of a teacher can be improved if there are factors that influence, both internal and external factors of a teacher. The strength of enthusiasm for someone to work actively in carrying out their duties depends on the reciprocal relationship between what is wanted and needed from the results of the work.

A teacher who is appointed as a teacher because he has a teacher certificate. Theoretically, teachers have the competence to carry out their duties. However, educational problems are increasingly complex for teachers to face alone. The teacher as an imperfect individual, there are still many that he does not know and master. Therefore, the teacher needs the help of others close to him to help him, namely; the principal .. the teacher as a social being, so that his competence is influenced by the effectiveness of the principal's supervision carried out at the school.

Harmonious relationships and solidarity will look better if there is support from the principal and peers at school. Teacher performance becomes high with active teacher participation in committee activities and decision making to solve school problems. Willingness to face the various characteristics of students and the proper use of time and energy can take place as long as the school athmosphere supports the smoothness of learning.

A poor school athmosphere will create low teacher performance and an unpleasant atmosphere among other school personnel. So that the vision and mission of the school are not carried out smoothly and the learning process is less or not maximally achieved, resulting in decreased student achievement. The relationship between teachers and staff is less harmonious, and teachers who are less involved in school decision making. Therefore, the school athmosphere is one of the things that needs to be considered in order to achieve quality educational institutions.

An open school athmosphere is characterized by cooperation and respect between teachers and school principals. The principal listens and is open to teacher suggestions, gives sincerity and praise, and respects the professional competence of the teacher. Principals can give teachers freedom to work with little supervision and restriction. Teacher behavior supports openness and professional interaction. The relationship between teachers and staff is less harmonious, and teachers who are less involved in school decision making. Therefore, the school athmosphere is one of the things that needs to be considered in order to achieve quality educational institutions.

1. The employees requires a conducive working environment, working environment, both physically and psychologically in order to foster a pleasant athmosphere in the works

2. There is working device in the form of adequate facilities for both basic equipment that must be present and supporting equipment to facilitate the settlement of workers so that the staff is able to display optimal results

3. Procedure and a clear technical work to foster an attitude of responsibility; and

4. The employees need encouragement and recognition of the success of accomplishment he gets.

Based on this literature, it can be seen that organizational athmosphere has an important role in building quality and quality schools. Organizational athmosphere can affect teacher performance, teacher behavior and attitudes, influence the learning process in class, and affect teacher participation in school activities. A bad organizational athmosphere will create low teacher performance and an unpleasant atmosphere among school personnel, so that the learning objectives are less or not maximally achieved, affecting student achievement. 


\section{Conclusions}

Based on the results of research and data analysis that has been carried out both descriptively and hypothesis testing, it can be concluded that: 1) There is an influence of organizational athmosphere on teacher performance at SMA PGRI 2 Palembang, 2) There is the influence on the performance of school leadership gur $u$ in SMA PGRI 2 Palemban, 3) There is an influence of organizational athmosphere and principal leadership on teacher performance at SMA PGRI 2 Palembang.

\section{References}

Albarobis, M. (2012). Educational Leadership Develops Cultural Character and School Achievements in a Changing Environment . Yogyakarta: PT Pustaka Insan Madani.

Arikunto, S. (2002). Research Procedure : A Practical Approach . Bandung: Alfabeta.

Aziz, WA (2011). Organizational Anatomy and Educational Leadership on the Organization and Management of Educational Organizations . Bandung: Alfabeta.

Bennis, WG (2010). Fundamentals of Organizational Leadership . trans. Sutarto, Jogjakarta: Gadjah Mada University Press.

Hayati., Musnadi., \& Faisal. (2018). Factors Affecting Job Satisfaction and Its Impact on Employee Performance at the Regional Office of the Directorate General of State Assets of Aceh. Jamal Master of Management, Volume 2, Number 1: 123-134.

Husein, L. (2017). Teaching Profession . Yogyakarta: New Library Press. 49.

Kirui. K., \& Osman, A. (2012). Headteachers' Perception of Their Roles in Secondary School in Kenya: A Study of Kerioho Day Secondary School in Ken'cho Country . International Jumal of Humanities and Social Science, Volume 2, Number 23; December 2012.

Luthans. F., \& Stajkovic, AD (2001). The Impact of Recognition on Employee Performance: Theory, Research and Practice . University of Nebraska, Department of Manage Lincoln.

Margono. (2003). Educational Research Methodology . Jakarta: PT Rineka Cipta.

Marphudok, Lian B . \& Fitria H ( 2020) The Effect of Work Environment and Work Motivation on the Performance of High School Teachers in Muara Padang District . Journal of Intellectuals: Islam, Social, and Science Vol. 9, No. 1, June 2020

Miles, A., \& Sledge, S. (2006). Satisfaction, Service and Culture: Relations from the Hotel Industry in Barzil, Mexico and Spain, Proceedings AIB-SE (USA) Annual Meeting: Clearwater Beach.

Purwanti. (2013). The Role of Principal Leadership in Improving Work Discipline for Teachers and Employees at Bakti Sejahtera High School, Kongbeng District, Kutai Tmur Regency . Public Administration Journal, Volume 1, Number 1: 210-224.

Puspitasari Y, Tobari \& Kesumawati N, ( 2021 ) The Effect of Principal Management and Teacher Professionalism on Teacher Performance . J urnal management, leadership, and education supervisors Volume 6, No. 1 January-June 2021

Puspowarsito. (2008). Organizational Research Methods Using SPSS Program Applications . Bandung: Humanities.

Sondang. (2006). Role of Staff in Management . Jakarta: CV. Masagung.

Sugiyono. (2013). Educational Research Methods Quantitative Approach, Qualitative and R \& D . Bandung: Alfabeta.

Upu, H. (2014) Education Quality Improvement in Indonesia. Proceeding of International Conference on Research, Implementation and Education of Mathematics and Sciences 2014 , Yogyakarta State University, 29-34.

Wahyudi, I. (2012). Human Resource Management . Jakarta: PT Bumi Aksara.

Wdoyoko., \& Putro, E. (2012). Techniques - Development of Research Instruments . Yogyakarta: Student Library.

Yulizar, A rafat Y. \& Rohana ( 2020 ) The Influence of Organizational Culture and Principal Leadership on Teacher Performance in SMA Negeri Tanjung Raja District . Journal of Intellectuals: Islam, Social, and Science Vol. 9, No. 1, June 2020 .

Yusuf, M. (2015). Quantitative Research Methods; Qualitative, and Combined Research . Jakarta: Prenadamedia. 